\title{
ANALISIS LAPORAN KEUANGAN DENGAN MENGGUNAKAN METODE TREND SEBAGAI DASAR MENILAI KONDISI PERUSAHAAN
}

\author{
ANALYSIS OF FINANCIAL STATEMENTS USING THE TREND METHOD \\ AS A BASIS TO ASSESS THE COMPANY'S CONDITIONS
}

\author{
Nur Ilmi Octaviani ${ }^{1}$, Erry Sunarya $^{2}$, Kokom Komariah $^{3}$ \\ Universitas Muhammadiyah Sukabumi ${ }^{1,2,3}$ \\ Nioctaviani@gmail.com ${ }^{1}$
}

\begin{abstract}
Financial statements are actually still a problem in a company that really needs to be taken seriously because the good and bad financial statements describe the company's financial condition. The purpose of this research is to find out how the company's financial condition and comparison of predictions of financial statements at PT. Three Pillars of Prosperous Food Tbk. The research method used in this study is a descriptive method with a quantitative approach, in which the authors collect data in the form of balance sheet financial position reports. Data collection techniques used were documentation and literature study. The results of this study indicate that there is a fluctuating development in the balance sheet and income statement, even in the balance sheet from year to year it also fluctuates, the income statement has increased from 2014 to 2016 and always decreases in 2017 Conclusion, by using trend analysis it can be predicted that the value of the postal year will come to experience a fluctuating development which is also the same as in previous years.
\end{abstract}

Keywords: Financial Statements, Trend Methods, Company Conditions

\begin{abstract}
ABSTRAK
Laporan keuangan sebenarnya masih menjadi permasalahan dalam sebuah perusahaan yang sangat perlu diperhatikan secara serius karena baik buruknya laporan keuangan menggambarkan kondisi keuangan perusahaan tersebut. Tujuan dari penelitian adalah untuk mengetahui bagaimana kondisi keuangan perusahaan dan perbandingan prediksi terhadap laporan keuangan pada PT. Tiga Pilar Sejahtera Food Tbk. Metode penelitian yang digunakan dalam penelitian ini adalah metode deskriptif dengan pendekatan kuantitatif, yang dimana penulis mengumpulkan data-data berupa laporan posisi keuangan neraca. Teknik pengumpulan data yang digunakan adalah dokumentasi dan studi kepustakaan. Hasil dari penelitian ini menunjukkan bahwa adanya perkembangan yang berfluktuasi pada laporan keuangan neraca dan juga laba rugi, pada laporan neraca dari tahun ke tahunya pun mengalami fluktuasi, pada laporan laba rugi mengalami peningkatan dari tahun 2014 sampai dengan tahun 2016 dan selalu mengalami penurunan pada tahun 2017. Simpulan, dengan menggunakan analisis trend dapat di prediksi bahwa nilai pos tahun yang akan datang akan mengalami perkembangan yang berfluktuasi juga sama dengan seperti tahun-tahun sebelumnya.
\end{abstract}

Kata Kunci : Laporan Keuangan, Metode Trend, Kondisi Perusahaan 


\section{PENDAHULUAN}

Laporan keuangan merupakan alat yang sangat penting untuk mendapatkan informasi mengenai posisi keuangan yang dicapai perusahaan, laporan keuangan juga dapat memberikan gambaran mengenai bagaimana kebijakan keuangan suatu perusahaan. Menganalisis laporan keuangan dapat menunjukkan apakah perusahaan mendapat pencapaian yang sangat bagus atau sebaliknya.

Laporan keuangan sebenarnya masih menjadi permasalahan dalam sebuah perusahaan yang sangat perlu diperhatikan secara serius karena baik buruknya laporan keuangan menggambarkan kondisi keuangan perusahaan tersebut. Perusahaan dapat mengetahui perkembangan keuangannya dapat dilihat dari laporan keuangan yang merupakan alat untuk memperoleh informasi posisi keuangan dan hasil yang sudah dicapai oleh perusahaan (Heri, 2015).

Dalam menganalisis laporan keuangan hampir setiap perusahaan melakukan analisis laporan keuangannya dengan yang seringkali digunakan dan diketahui yaitu analisis rasio, yaitu dengan menilai tingkat likuiditas, solvabilitas, profitabilitas, dan rasio pasar suatu perusahaan (Warsono, 2003). Akan tetapi analisis rasio memiliki kelemahan yaitu tidak membandingkan semua nilai yang ada dalam laporan keuangan secara lebih detail. Kelemahan analisis rasio tersebut tidak terdapat pada analisis laporan keuangan dengan bentuk metode trend. Analisis metode trend ini dapat membandingkan semua nilai yang terdapat dalam laporan keuangan dan sesuai dengan apa yang akan dibandingkan (Prastowo, 2011).

Dalam penelitian ini penulis akan menganalisis laporan keuangan dengan menggunakan metode trend pada PT.
Tiga Pilar Sejahtera Food Tbk, dalam analisis laporan keuangan ini akan membandingkan semua nilai yag ada didalam laporan keuangan, yang dilihat pada laporan keuangan neraca dan laba rugi pada periode 2013 sampai dengan 2017.

Menurut Munawir (2010) pada umumnya laporan keuangan itu terdiri dari neraca dan juga perhitungan labarugi serta laporan perubahan ekuitas. Neraca menunjukkan atau menggambarkan jumlah asset, kewajiban dan ekuitas dari suatu perusahaan pada tanggal tertentu".

Dalam menilai kondisi keuangan perusahaan tersebut dilakukan yaitu untuk mengetahui sejauh mana kondisi keuangan perusahaan nya yang terlihat dari laporan keuangan dari tahun ke tahun. Gambaran dari kondisi atau kinerja keuangan perusahaan dapat dilihat dengan melakukan analisis laporan keuanga, sehingga hasil dari analisis laporan keuangan tersebut dapat memberikan informasi bagi pihak yang berkepentingan dengan perusahaan.

Dalam menganalisis laporan keuangan, haruslah memiliki bentuk maupun prinsip dalam penyusunan laporan keuangan serta masalah yang mungkin akan timbul dalam penyusunan laporan keuangan. Laporan keuangan terdiri dari (Harahap, 2004) :

1. Laporan Neraca merupakan posisi keuangan perusahaan pada kurun waktu tertentu, laporan neraca menunjukkan aktiva, hutang dan modal suatu perusahaan pada periode terakhir. Pos aktiva menunjukkan penggunaan dana, hutang dan modal yang diperoleh. Laporan enraca bertujuan untuk memperlihatkan posisi keuangan pada suatu perusahaan pada tanggal tertentu, biasanya pada waktu buku-buku ditutup dan ditentukan pada akhir 
tahun sehingga neraca disebut dengan balance sheet.

2. Laporan Laba Rugi. Laporan laba rugi merupakan laporan yang menggambarkan jumlah dari penghasilan suatu perusahaan pada periode tertentu, dan laporan laba rugi disusun tiap akhir tahun.

3. Laporan Arus Kas. Merupakan laporan yang menggambarkan mengenai perputaran uang selama periode tertentu, misalnya bulanan dan tahunan. Laporan arus kas terdiri dari kas untuk kegiatan operasional dank as untuk kegiatan pendanaan.

\section{METODE PENELITIAN}

Menurut Munawir (2010) analisis trend merupakan suatu metode atau teknik analisis untuk mengetahui tendensi dari pada keadaan keuangannya, apakah menunjukkan tendensi tetap, naik atau bahkan turun. Penelitian ini dilakukan melalui pendekatan kuantitatif dengan perhitungan trend terhadap laporan keuangan PT Tiga Pilar Periode tahun 2013 hingga tahun 2017.

Adapun langkah dalam melakukan analisis trend adalah sebagai berikut :

1. Menentukan terlebih dahulu tahun dasar, tahun dasar ini ditentukan dari tahun perubahan atau reorganisasi serta tahun lainnya, tahun dasar dicatat sebagai indeks 100.

2. Menghitung angka indeks dari tahun-tahun lainnya yaitu dengan menggunakan angka laporan keuangan tahun dasar sebagai penyebut.

3. Memperkirakan kecenderungan yang mungkin akan terjadi berdasarkan arah dari historis pos laporan keuangan yang dianalisis.

4. Mengambil keputusan mengenai hal-hal yang harus dilakukan untuk mengantisipasi kecenderungan itu.
Rumus dari analisis trend adalah :

$$
\text { Angka indeks }=\frac{\text { Tahun pembanding }}{\text { Tahun dasar }} \times 100 \%
$$

\section{HASIL DAN PEMBAHASAN}

Berikut merupakan hasil perhitungan metode Trend pada neraca PT Tiga Pilar Sejahtera Food Tbk :

Tabel 1. Metode Trend Pada Neraca PT. Tiga Pilar Sejahtera Food Tbk

\begin{tabular}{lccccc}
\hline & $\mathbf{2 0 1 3}$ & $\mathbf{2 0 1 4}$ & $\mathbf{2 0 1 5}$ & $\mathbf{2 0 1 6}$ & $\mathbf{2 0 1 7}$ \\
\hline Kas & $100 \%$ & $384 \%$ & $186 \%$ & $93 \%$ & $57 \%$ \\
\hline Persediaan & $100 \%$ & $121 \%$ & $153 \%$ & $202 \%$ & $137 \%$ \\
\hline $\begin{array}{l}\text { Jumlah Aset } \\
\text { Lancar }\end{array}$ & $100 \%$ & $163 \%$ & $183 \%$ & $243 \%$ & $186 \%$ \\
\hline $\begin{array}{l}\text { Aset Tetap } \\
\text { Jumlah Aset }\end{array}$ & $100 \%$ & $124 \%$ & $159 \%$ & $179 \%$ & $220 \%$ \\
$\begin{array}{l}\text { Tidak } \\
\text { Lancar }\end{array}$ & & $132 \%$ & $178 \%$ & $128 \%$ & $162 \%$ \\
\hline $\begin{array}{l}\text { Jumlah Aset } \\
\text { Liabilitas }\end{array}$ & $100 \%$ & $147 \%$ & $180 \%$ & $184 \%$ & $174 \%$ \\
\hline $\begin{array}{l}\text { Jangka } \\
\text { Pendek }\end{array}$ & $100 \%$ & $107 \%$ & $197 \%$ & $179 \%$ & $279 \%$ \\
\hline $\begin{array}{l}\text { Liabilitas } \\
\text { Jangka } \\
\text { Panjang }\end{array}$ & $100 \%$ & $180 \%$ & $185 \%$ & $196 \%$ & $350 \%$ \\
\hline $\begin{array}{l}\text { Jumlah } \\
\text { Liabilitas }\end{array}$ & $100 \%$ & $142 \%$ & $191 \%$ & $187 \%$ & $200 \%$ \\
\hline $\begin{array}{l}\text { Jumlah } \\
\text { Ekuitas }\end{array}$ & $100 \%$ & $152 \%$ & $168 \%$ & $181 \%$ & $144 \%$ \\
\hline $\begin{array}{l}\text { Jumlah } \\
\text { Ekuitas dan } \\
\text { Liabilitas }\end{array}$ & $100 \%$ & $147 \%$ & $180 \%$ & $184 \%$ & $174 \%$ \\
\hline $\begin{array}{l}\text { Sumber : Dat } \\
\text { Jum }\end{array}$ & & & & & \\
\hline & & & & & \\
\hline & & & & & \\
\hline
\end{tabular}

Sumber : Data olahan (2018)

Perkembangan kondisi keuangan perusahaan dengan menggunakan analisis trend mengalami perkembangan yang berfluktuasi, dilihat dari perkembangan trend aset lancar PT. TPS pada tahun 2015 terjadi peningkatan sebesar $183 \%$ dari tahun sebelumnya, hal ini disebabkan karena persediaan pada tahun tersebut meningkat juga sebesar $153 \%$ dari tahun sebelumnya. Pada tahun 2016 terjadi peningkatan yang signifikan yaitu $243 \%$, akan tetatpi pada tahun 2017 mengalami penurunan pada aset lancar nya sebesar $186 \%$ hal ini 
dikarenakan oleh turunnya proporsi persediaan sebesar $137 \%$.

Perkembangan trend aset tidak lancar PT. TPS mengalami perkembangan yang fluktuasi juga, penurunan yang paling besar proporsi nya terjadi pada tahun 2016 yaitu sebesar $128 \%$ dari tahun-tahun sebelumnya.

Selanjutnya hasil analisis untuk total aset menunjukkan perkembangan yang mengalami fluktuasi dengan tendensi meningkat dari tahun 2014 sampai dengan tahun 2016, dan mengalami penurunan pada tahun 2017 sebesar $174 \%$.

Tabel 2. Metode Trend Pada Laba Rugi PT. Tiga Pilar Sejahtera Food Tbk

\begin{tabular}{llllll}
\hline & $\mathbf{2 0 1 3}$ & $\mathbf{2 0 1 4}$ & $\mathbf{2 0 1 5}$ & $\mathbf{2 0 1 6}$ & $\mathbf{2 0 1 7}$ \\
\hline Penjualan & $100 \%$ & $127 \%$ & $148 \%$ & $161 \%$ & $121 \%$ \\
\hline $\begin{array}{l}\text { Beban } \\
\text { Pokok } \\
\text { Penjualan }\end{array}$ & $100 \%$ & $130 \%$ & $151 \%$ & $155 \%$ & $137 \%$ \\
\hline $\begin{array}{l}\text { Laba } \\
\text { Kotor }\end{array}$ & $100 \%$ & $114 \%$ & $139 \%$ & $184 \%$ & $69 \%$ \\
\hline $\begin{array}{l}\text { Laba } \\
\text { Bersih }\end{array}$ & $100 \%$ & $109 \%$ & $108 \%$ & $207 \%$ & $-244 \%$ \\
\hline \begin{tabular}{l} 
Sumber \\
\hline
\end{tabular} & & & & & \\
\hline
\end{tabular}

Sumber : Data olahan (2018)

Hasil analisis trend pada pos penjualan mengalami fluktuasi dan cenderung meningkat seperti terlihat pada tabel diatas, mengalami peningkatan dari tahun 2014 sampai dengan tahun 2016 dan mengalami pada tahun 2017 sebesar $121 \%$ dari tahun sebelumnya. Perkembangan yang berfluktuasi juga terjadi pos beban pokok penjualan yang juga mengalami penurunan pada tahun 2017 sebesar 137\% dari tahun yang sebelumnya. Pada pos laba bersih dapat dilihat mengalami peningkatan yang berfluktuasi, pada tahun 2015 mengalami penurunan yang sangat tipis dari tahun sebelumnya, lalu mengalami kenaikan pada tahun 2016 sebesar $207 \%$ dan kembali mengalami penurunan yang sangat signifikan yaitu sebesar $-244 \%$.
Analisis trend yang dilakukan bertujuan untuk mengetahui tendensi atau kecenderungan keadaan keuangan suatu perusahaan di masa yang akan datang baik kecenderungan akan naik, turun maupun tetap (Veno 2016). Manfaat analisa tren bagi investor yaitu untuk kebutuhan informasi yang akurat mengenai aktivitas maupun posisi keuangan perusahaan, apakah pada masa mendatang menghasilkan laba atau sebaliknya. Bagi Pemberi pinjaman atau kreditur tertarik dengan informasi yang disediakan oleh perusahaan khususnya keuangan, yang memungkinkan mereka untuk memutuskan apakah dana yang tertanam di dalam perusahaan dapat dibayarkan kembali tepat waktu oleh perusahaan (Munawir 2004).

Bagi Manajemen dapat terbantu dalam hal tanggung jawab, perencanaan, pengendalian, dan pengambilan keputusan berdasarkan hasil analisa. Analisa tren ini bermanfaat untuk menilai situasi "tren" perusahaan yang telah lalu serta dapat memprediksi tren perusahaan di masa yang akan datang berdasarkan garis tren yang sudah terjadi. Hasil penelitian ini telah memberikan masukan bagi PT Tiga Pilar Sejahtera Food Tbk.

\section{PENUTUP \\ Kesimpulan}

Berdasarkan hasil penelitian dapat ditarik kesimpulan bahwa kinerja perusahaan selama periode 2013 sampai dengan 2017, analisis trend yang dilakukan pada laporan neraca pada pos total aset dan jumlah ekuitas menunjukkan perkembangan yang meningkat di setiap tahun nya akan tetapi mengalami penurunan pada satu tahun terakhir yang dimana penurunannya pada tahun 2017.

Sedangkan analisis trend yang dilakukan pada laporan labarugi 
menunjukkan bahwa setiap pos yang ada pada laporan laba rugi mengalami perkembangan yang berfluktuasi. Jika trend suatu pos mengalami kecenderungan meningkat, maka dapat diprediksi bahwa nilai pos tahun berikutnya juga akan meningkat dan begitu pula sebaliknya. Dari hasil penelitian dengan menggunakan analisis trend dapat di prediksi bahwa nilai pos tahun yang akan datang akan mengalami perkembangan yang berfluktuasi juga sama dengan seperti tahun-tahun sebelumnya.

\section{Saran}

Melalui analisa trend yang telah dilakukan, maka diharapkan pihak manajemen PT Tiga Pilar Sejahtera Food Tbk dapat merumuskan strategi yang tepat untuk tetap mempertahankan peningkatan keuangan perusahaan di tahun-tahun berikutnya.

DAFTAR PUSTAKA

Harahap, S.,S. (2004). Akuntansi Aktiva Tetap, Edisi ketiga, Jakarta: Penerbit PT. Raja Grafindo.

Hery, (2015). Analisis Laporan Keuangan. Yogyakarta : CAPS (Center for Academic Publishing Service).

Munawir, (2010), Analisis Laporan Keuangan, edisi keempat, cetakan ketiga belas, Yogyakarta : Liberty. Prastowo, D. (2011). Analisis Laporan Keuangan (Konsep dan Aplikasi). Edisi Ketiga. Yogyakarta : UPP STIM YKPN.

Veno, A.,S. (2016). Analisis Kinerja Keuangan Perbankan Syariah Tahun 2015 Sampai Dengan 2017. Jurnal Bisnis dan Manajemen Islam, 4(1)
Warsono.(2003). Manajemen Keuangan Perusahaan. Jilid 1. Malang:Bayu Media Publishing. 